tud $\$ 75.17$

Yu. N. Alezandrov

\title{
Mutagenesis induced by polynucleotides
}

A review of the modem condition of the problem of mutagenesis by means of polynucleotides of natural and artifical origin Peculiarities and regularities of their mutagene activity have been characterized. The received results give new information about the nature unstability of genes and the transpositions regulority. The problem of mutagen activity of polynucleotides is being discussed in the field of the gypothesis of insertion mutagenesis.

Fore more than a half of a century geneticists have carried out the artifical mutagenes ( $x$-rays, alkyl compounds and other chemical substances). They are used now a rule only increase (sometimes substantially) the general frequency of mutations but don't change radically their spectrum at least in eukaryots. In other words, general frequency of mutations of different genes stays approximately the same as without experimental interference. Genes that are characterized by rather high frequency of spontaneous mutations change especially often by usual use of mutagenic factors; but genes that have a low ability to give natural mutations continue to mutate relatively less in the time of influence of these mutagenes.

The remarkable discovery of the mutagenic effect of DNA [1] had fundamental importance for subsequent genetic investigations. First, the role which DNA can play in genetic processes was demonstrated; second, a strong chemical mutagen, unlike the rather weak ones discovered earlier, was found [2, 3]; third, the obtainment of specific mutations was one of the most important results. All these facts together promoted in the future the rapid development of investigations in the area of chemical mutagenesis.

In the preface to his work, Gershenson indicated that the work was carried out "on the basis of a number of theoretical considerations concerning the nature of chromosomes, and also on the basis of facts obtained in recent years with respect to the role played by nucleic acid in realizing hereditary characters" [1].

Originally in investigations on mutagenesis experiments were set up by means of one type of DNA - a preparation isolated from the calf thymus (mol. wt. $0.5-1.0$ million), which was mixed into the food of Drosophila larvae. The methods used made it possible to detect visible recessive and dominant mutations on the $X$ chromosome, visible dominant mutations in autosomes, and recessive lethal mutations in the $\mathrm{X}$ chromosome. It was found that preparations of this DNA induce in Drosophila numerous sex-linked and autosomal visible mutations and only an insignificant number of sex-linked lethals [4, 5 ].

The main results obtained under the effect of DNA on Drosophila can be formulated in the following way: the spectrum of induced mutations radically differed from the spectrum of spontaneous mutations or mutations induced by other chemical or physical mutagens; DNA induced point mutations, $i$. e., gene mutations or microaberrations, but did not induce large chromosomal aberrations; DNA had a prolonged mutagenic effect, it induced mutations not only in sex and somatic cells present at the time of injecting DNA into Drosophila, but also in many subsequent generations; certain DNA-induced gene mutations 
were unstable: they often reverted to the norm or passed into another allelic state.

On the basis of these results, still at the dawn of development of investigations in the area of chemical mutagenesis, Gershenson expressed ideas at which molecular genetics arrive only 25 years later. He wrote: "Our estabilished fact ... should be interpreted as evidence in behalf of the fact that a change in the part of the chromosome molecule consisting of DNA actually can induce a gene mutation. ... The especially frequent mutation of certain genes under the effect of our DNA preparation leads to the notion of a different themical structure of DNA of different gene molecules. So far we more or less satisfactorily know the stracture only of DNA from the calf thymus and it simply cannot be ruled out that there exists numerous other DNAs having the same carbohydrate (deoxyribose) and therefore producing the same Feulgen reaction but differing in the character and arrangement of other parts. ... The consequences of feeding (Drosophila) DNA can be explained most easily by the assumption that the effect used disrupts the process of reproduction of genes, as a result of which the newly formed genes sometimes differ in their structure from the original ones. If such an explanation is correct, it means that DNA plays an important role in the reproduction of genes" [5].

Works on the induction of mutations by means of DNA in Drosophila continued (with interruptions) and constantly gave the same surprising and interesting results [6]. Subsequently, when the emphasis of investigations was transferred from visible mutations to the obtainment of primarily lethal mutations (mainly in the second chromosome) as an objectively recordable class of pronounced alterations giving information on at least $80 \%$ of the loci of the genome and the injection of DNA preparations began to be used instead of feeding, the main conclusions about the specific characteristics of the mutagenic effect of DNA were confirmed and extended [7-11]. It was found that DNA of different origins (more than 10 preparations with a molecular weight from 2 to 33 million isolated from animals, plants, and viruses were studied) induces a limited number of repeatediy occurring lethal mutations, and the frequency of mutations per locus reaches enonmous values, exceeding by hundreds and thousands of times the analogous frequency of mutations occurring under the effect of various physical and chemrical mutagens. The complementation test as one of the most important criteria for establishing the selectivity of the effect of mutagens revealed still another surprising property ot the mutagenic effect of DNA preparations - complex allelic rations existed between chromosomes with lethals. The sense of this phenomenon in the simplest case consisted in that two chromosomes separately allelic to a third were not allelic to each other. Such interrelations of defects induced in chromosomes could be explained by transgressing deletions, interallelic complementation, and presence of lethals in different loci of the chromosomes. Only the last assumption found experimenta) confirmation of this interesting phenomenon. It was postulated by a mathematicai analysis [12] and proved by direct experiment in which the complementation data were compared with the data of a recombination analysis $\{1\}$, $14 \mathrm{~J}$. According to the calculations, about $50 \%$ of chromosomes in which lethal mutations occur under the effect of exogenous DNA should be considered multilethal. Thus the occurrence of multilethal chromosomes and the large number of "allelic linkages" reflects still another important characteristic of the mutagenic effect of exogenous DNAs.

It followed from the experiments on complementation and also in cases of genetic mapping that each DNA preparation had, as a rule, its own characteristic spectrum of lethal mutations differing from the spectrum of DNAinduced mutations from other organisms; however, these differences were not absolute, and almost always loci of a common occurrence were found. Evidently, 
the selectivity of the mutagenic effect of each of the investigated DNA preparations was determined by two components. The main one is the specificity of the effect of a given mutagen, and the second, having a subordinate value, characterizes genes or segments of chromosomes especially sensitive to the effect of these mutagens.

Experiments on a comparative study of the mutagenic activity of different natural DNAs led, in addition to the aforementioned regularities, to a number of interesting conclusions. The most important of them are as follows: 1) DNA of a different species origin exhibits a different mutagenic activity; 2) the specificity of the mutagenic effect of heterologous and homologous DNA is different. Whereas as heterologous DNAs have, as a rule, a high intrachromosomal specificity, homologous DNA is characterized by the absence of such; 3) cells of the premeiotic stage of gametogenesis of Drosophila are more sensitive to the mutagenic effect of DNA; 4) DNA can induce direct mutations, reversions, and transpositions $[11,15-20]$.

It is important to note that the mutagenic effect of DNA after the fundamental works of Gershenson was established by a number of other investigators working with Drosophila $[21-30]$. Numerous authors showed that DNA is mutagenic also for other organisms - bacteria [31, 32], blue-green algae $[33]$, fungi $[34]$, higher plants $[35]$, insects [36], and mammals $[37$, $38 \mathrm{j}$. Thus the discovery of the mutagenic properties of exogenous DNA gained complete recognition [ 39 ].

Gershenson's works on the mutagenic effect of DNA found their logical continuation in a study of the mutagenic effect of viruses not infections for Drosophila and artificially synthesized polynucleotides. It was found that only the nucieic acid of viruses, but not their proteins, has a mutagenic principle and, as a consequence of this, a high selectivity of the mutagenic effect of viruses. All unique properties which were characteristic of the preparations of exogenous DNAs were demonstrated analogously in a study of mutagenesis by means of viruses and high-poiymer artificial polynucleotides $[10,40,41]$.

The true nature of the mutagenic effect of DNA has still not been completely explained, although since the time of the discovery of this phenomenon more than 50 years have passed. It is now assumed than DNAs induce mutations of the insertion rype, being incorporated into genomes at places of incompjete homology 1421. This is indicated both by indirect data on a comparison of the characteristics of mutations induced by exogenous DNAs and spontaneous insertion mutations in Drosophila [43] (locus specificity, high total frequency of mutations and high frequency of mutations per locus, cluster occurrence of mutations in the premeiotic stage of gametogenesis, instability) and by recently conducted direct experiments to establish the sequences of exogenous DNA in the Drosophila genome, for which this DNA was mutagenic [44]. The prolonged effect of exogenous DNAs can be explained by the fact that fragments of molecules (probably forming rings) injected into Drosophila are present in the cytoplasm either in a free state and are transmitted from one generation of cells to another or are inserted into the chromosome of the recipient, causing gene mutations or microaberrations. The detected instabilities of certain mutations are most probably caused by excision of the inserted fragments of exogenous DNAs or by change in their orientation in the chromosome. On the basis of this hypothesis the absence of mutagenic locus specificity in homologous DNA becomes understandable. Fragments of this DNA of Drosophila with respect to their physical characteristics and nucleotide sequences correspond to a multitude of loci of Drosophila chromosomes, whereas only few fragments of heterologous DNAs can have a random affinity with the extremely limited number of loci.

The supposition was also expressed that polynucleotides of natural and 
artificial origin injected into Drosophila could be another way to act on the genome - by activation of its mobile element (MEs), which by their translocations could cause mutations of certain genes [41]. The possibility of such a way of inducing mutations by exogenous polynucleotides is indirectly confirmed by the discovery of the phenomenon of so-called transposition explosions, when it was possible to observe mass translocations of MEs accompanied by multiple mutation events [45, 46]. The multilethal chromosomes detected in experiments on mutagenesis by means of DNA, viruses, and synthetic polynucleotides with the simultaneous occurrence of a large number of mutations in them is the result of unique mutation "explosions", which probably should be preceded by the "transposition explosions". If the interlinked character of these events will be proved in the future, it will serve as still another weighty argument in behalf of the insertion nature of the mutagenic effect of exogenous polynucleotides, although in this case fragments of DNA of an endogenous origin will be insertions.

Thus, generalization the aforesaid, we would like to emphasize once again the important role of the discovery of the mutagenic effect of exogenous DNAs - their high mutagenecity, selectivity of action, and nontoxicity [47, 48 ].

It is still premature to speak about the practical use of these substances on a wide scale, nevertheless exogenous DNA was the first chemical substance which engendered in geneticists the hope of inducing mutations of certain genes in higher organisms, which would be of enormous value for practical breeding.

This gives possibility to hope that in the future by testing the mutagen activity of different DNAs and especially artificial polynucleotides with the know structure. It will also be possible to find the way in selected induction of mutations that change phenotype into the definite side.

\section{R. M. Azercandpos}

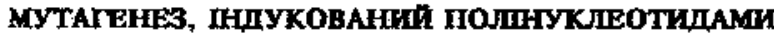

\section{Pequane}

Зробдено огляд сучасного стану проблемя мутатенезу за допомогожо полінуклеотдів природного і штучного походження, Охарактеривовано особлнвості і закономірності іx муталенної дії. Отрияані результати дакоть нові відомості цодо природи нестабільності генів і закономірностях

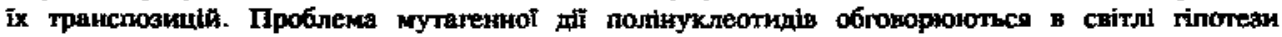
ifcepuithoro mytaresesy

\section{REFERENCES}

1. Gershenson S. M. Induction of directed muthtions in Drosophpla melonogaster // Dolk. AN SSSR.-1939.-25, N 2.-P. 224-227.

2. Sakharov $V, V$. lodine as a chemical factor acting on the mutation process in Drosophila melanogater // Biol. Zhurn.-1932.-1, N 3/4.-P. 1-8.

3. Labashev M. E. Smimov F. A. Nature of the effect of chemical agents on the wutation process in Drasophila melanogaster // Dokl. AN SSSR.-1934.-2, N 5.-P. 174-178.

4. Gershenson S. M. Character of mutation in Drosophila by the sodium salt of DNA // Ibid. $-1940 .-26, \mathrm{~N}$ 6.-P. $609-611$.

5. Gersgenson S. V., Zitberman R. A., Levochkina $O$. A. et al. Induction of mutations in Drosophila by DNA // Zum. Obshch. Biol._1948.-9, N 1.-P. 69-78.

6. Gershenson S. M., Kiseleva $I$. A. Jaduction of directed heritable alterations in Drasophila melanogaster // DokJ. AN SSSR.-1958.-123, N 3.-P. 554-558.

7. Gershenson $S$. $M$. Induction of lethal mutations by DNA in Drosophila melonogaster // Zhum. Obshch. Biol.-1964.-25, N 5.-P. 371-375.

8. Gershenson $S$. $M$. Induction of lethal muthtion in Drosophila metanogenter by DNA // Genet. Res. $-1965 .-6$, N 2.-P. $157-162$.

9. Gershension S. M. Mutagenic effect of DNA and the problem of directed mutwions // Genetika.-1966,-2, N 5,-P. 3-13. 
10. Gershenson S. M., Alexandrov Yu. N., Malyuta S. S. Mutagenic effect on DNA and viruses in Drosophila. - Kiev: Nauk. dumka, 1975.-160 p.

11. Dyachenko $S$. $S$., Alexandrov $Y_{u}$. $N$. Relation between mutagenic effect and species origin of DNA // Mol. Biologiya.-1976. -N 14.-P. 3-9.

12. Rodin $S$. N. Analysis of allelic ratios of recessive lethats induced in Drosophila by exogenous DNAs and certain vinuses // Genetika._1974.-10, N 9.-P. 94-105.

13. Alexandrov $Y_{u}$. N., Golubovsky $M . D$. Role of viruses and exogenous DNA in the natural mutation process. Experimentai investigations on Drosophila // Ibid.-1983. - 19, N 11.P. $1818-1827$.

14. Alexandrov Yu N., Golubovsky $M$. D. The multisite mutation induced by viruses and foreign DNA can spread in natural populations of Drosophila // Drosophila Inform. Serv.-1983.-59, N 1.-P. 10-11.

15. Gershenson $S . M .$, Alexandrov $Y_{u} . N$. Mutagenic effect of natural and synthetic polynucleotides and problem of directed mutations // Zhum. Obshch. Biol. $-1982,-43, \mathbf{N} 6 .-\mathrm{P} .747-763$.

16. Alexandrov $Y_{u} N$. Study of the possibility of inducing dominant lethal mutations in Drosophila by means of exogenous DNAs // Mol. Biologiya.-1975.-N 12.-P. 128-130.

17. Dyachenko S. S., Alexandrov $Y_{L L}$. N. Ability of heterogenous DNA to induce gene mutations in Drosophila // Tsitologiya i Genetika.-1973.-7, N 2.-P. 171-172.

18. Gershenson $S$. $M$. Mutagenic effect of DNA, insertions, transpositions, and unstable genes // Transactions of the fourteenth Int. genet. congr. (Moscow, august 1978). - Moscow: Nauka, 1981.-P. 304-318.

19. Shandala $T$. V., Alexandrov $Y_{L}$ N., Gershenson $S . M$. High locus specificity of the mutagenic effect of viral DNA in the induction of visible mutations in Drasophila // Dokl. AN SSSR.-1983.-N 11.-P. 84-87.

20. Aizenzon $M$. $G$. Instability of the locatization and expression of atlele Thickened 2 of Drosophila melanogaster // Tsitologiya i Genetika.-1985.-19, N 3.-P. 172-175.

21. Fahmy O. G. Fahmy M. J. Induction of mutation by deoxyribonucleic acid in Drosophila melanogaster // Nature.-1961.-191, N 4790.-P. 776-779.

22. Fahmy $O$. G., Fahmy $M$. J. The nature and distribution of the mutations induced by unirradiated and irradiated heterołogous deoxyribonucieic acid in Drosophila melanogaster. // Genetics.m-1966.-54, N 5.-.P. 1123-1138.

23. Parkash $O$. Induction of sex-linked recessive lethals and visible muthtions by feeding X-irradiated DNA to Drosophila melanogaster // Nature.-1965.-214, N 5086.-P. 611 612 .

24. Mathew $C$. The production of recessive lethals by calf-thymus DNA in Drosophila // Genet. Res. $-1965 .-6$, N 2.-P. $163-174$.

25. Khan A. H., Alderson T. Mutagenic effect of irradiated and unirradiated DNA in Drosophila // Nature. -1965.-208, N 5011.-P. 700-702.

26. Chopra V. $L$. DNA feeding and directed mutagenesis in Drosophila melanogaster // Genet. Res.-1970.-15. N 3.-P. 345-346.

27. Chukla $P$. $T$. Analysis of mutagen specificity in Drosophila melanogaster // Mutat. Res.1972.-16, N 1.-P. 363-368.

28. Jain H. K. Chukla P. T. Locus specificity of mutations in Drosophilo // Ibid.-14, N 2.-P. $440 \longrightarrow 445$.

29. Fox A. S., Yoon S. B. Specific genetic effects of DNA in Drosophila melanogaster // Genetics.-1966.--53, N 5.-P. 897-911.

30. Ondrej $M$. Geneticle vivy cistorode DNA in eukaryot // Biol. Listy.-1974.—N 39.-P. 98103.

31. Mergeay $M$. Mutagenic effect of Streptomyces coelicor DNA detected after streptomycin treatment of competent cultures of Bacillus subtilis // Mol. and Gen. Genet.-1972.-119, N $1, \rightarrow$ P. 89-94.

32. Karpova $I$. S. Bacillus subtilis mutants isolated after the effect of exogenous DNA on a B. subtilis culture // DokJ. AN USSR. Ser. B.-1975.-N 5.-P. 169.

33. Herdman $M$. Mutations arising during transformation in the green-blue alga Anacystis nidulans // Mol. and Gen. Genet.1973.-120, N 3.-P. 369-378.

34. Sobels $J$. C. Mutagenic effect of DNA in Aspergillus nidulans // Aspergillus News Lett.1965.-6, N 1.-P. $11-12$.

35. Kortel N. A. Effects of exogenous DNA in higher plants. - Minsk: Nauka i tekhnika, $1981 .-130 \mathrm{p}$.

36. Nawa S., Sakaguchi B., Yamada M., Tsujita $M$. Hereditary change in Bombyx after trearment with DNA //Genetics.-1971.-67, N 2.-P. 221-234.

37. Karpfel $Z$., Slotova $J$, Palecek $E$. Chromosome aberrations produced by deoxyribonucleic acids in mice // Exp. Cell. Res.-1963.-32.-P. 147-148.

38. Borenfreund E., Fonda Y., Steinglass M., Bendich A. Studies of DNA-induced hereditable alteration of mammalian cells // Bbid.-1970.-132.-P. 1071-1089.

39. Auerbach C. Problems of mutagenesis. - Moscow: Mir, 1978. -470 p. 
40. Alexandrov $Y_{u} . N$. Mutagenic effect on Drosophila of certain viruses of insects and their individual components // Use of experimental mutations in plant breeding. - Ktev: Nauk. dumka, 1973.-P. 27.

41. Alexandrov $Y u$ N., Gershenson S. M. Selective mutagenic effect of synthetic polyaucleotides $/ /$ Biopolymers and Celt.-1985.-1, N 1.-P. $21-25$.

42. Alexandiov $Y_{u}$. N., Gershenson $S . M$. Specificity of the mutagenic effect of DNA of various origin // Molecular mechanism of genetic processes. - Moscow, 1976.-P. 14-16.

43. Gerasimove $T$. I. Hybrid dysgenesis, mutator systems, and instabillty faciors in Drasophila melonogoster: Data of genetic and molecular biological investigation // Genetika._1981.-17, N 5.-P. 773-781.

44. Gazoryan $K$ G., Nobirochkin S. D., Shakhbezyan A. $K$ et al Inductton of unstable mutstions in Drasophilo melanogester by microinjection oncogenic viruses and their DNA into early enbryos // Ibid. $-1984 .-20$, N 8.-P. 1237-1243.

45. Gerasimova T. I., Mizrothi $L$. Yu, Georgiev G. P. Transposition explosions in indtvidual germ cells in unstable Drosophila meinnogaster lines // Dokl. AN SSSR.-1984,-274, N 6.P. 1473-1476.

46. Gerasimova T. I., Matyunina L V., Mizrakhi L Yu. et al. Multiple transposition events in individual germinal cells in unstable Drosophila lines // Genetika.-1984.-20, N 9.P. 1434-1443.

47. Colubovsky $M$., Koidanov $L$ Iavestigation of genetic variability in natural Drosophila populations // Biopolymers and Cell_-1994-10, N S.-P. 49-67.

48. Golubovsky $M$. Mobile genetics and forms of heritable changes in eukaryotes $/ /$ Ibid. -1995 .11, N 2.-P. 29-38.

Inst. of Plant Physiol. and Genet.

Nat Acad. of Sci. of the Ukraine, Kyiy 